\author{
Amin Samman \\ City University London, UK
}

\title{
Ghosts in the machine
}

Since at least the nineteenth century, economists have imagined the market as a profoundly rational way of organizing society. Unlike other modes of economic organization, the market is governed by natural laws that ensure the most efficient possible allocation of resources. Modern financial economists take this logic even further, seeing new financial instruments as a means of efficiently managing risk. These visions betray a mechanical conception of economy. Like a well-oiled machine, buyers and sellers play their part in a larger whole, balancing each other out and enabling practical reason to lead societies to ever-greater levels of prosperity.

In many ways the contemporary financial economy does look like a machine. Think, for example, of its Bloomberg terminals, its automated trading systems, and its algorithm wars. But if global finance is a machine, then there is something irrational, something supernatural - even magical - about the way it operates. It is not just the periodic bouts of mania, panic, and crisis; nor is it the apparently endless drive to accumulate, to conjure more and more wealth out of a void. It is that in these and other processes, a range of psychic investments are at work - curious attachments that bind us to money, to projected futures, to imaginary orders, and ultimately, to the modes of power upon which capitalism depends. The magical parts make and move the mechanical whole. This, at least, is the controversial idea developed in a string of new books to which this forum is dedicated.

In What Money Wants (2014), Noam Yuran suggests that money is best viewed as an object of desire - a thing without qualities that moves through and shapes human history, inducing its owners to engage in frantic, aimless, and endless activity. Money, too, is the focus of Martijn Konings' book, The Emotional Logic of Capitalism (2015). For Konings, however, money should be understood in semiotic terms - not as a mere sign but as an icon, an affective sign through which particular kinds of money economies are produced. In both books, money is neither a simple tool nor a mere figment of the collective imagination - it is something to which we are bound through the magic of fantasy.

Money's fantastical dimensions also take center stage in the recent work of Joseph Vogl and Paul Crosthwaite. For Vogl and Crosthwaite, money is indeed a peculiar thing, leaving behind itself a long trail of metaphysical anxiety. But for both authors, these anxieties are fundamentally reconfigured when money becomes credit. In The Specter of Capital (2015),

\section{Corresponding author:}

Amin Samman, Department of International Politics, City University London, Northampton Square, EC1V OHB, UK. Email: amin.samman.1@city.ac.uk 
Vogl charts the progressive transformation of ancient fears about moneymaking into a baseless regime of postmodern finance. With the derivatives revolution of the $1980 \mathrm{~s}$, he argues, capitalism becomes a specular machine - a semi-automatic information system, forever feeding off and haunted by the statistical futures it produces. In Crosthwaite's forthcoming book, Speculative Investments, financial markets are equally spectral, but instead of the all-seeing machine he finds the all-believing subject-analysts, traders, and fund managers, even central bankers, all thick as thieves with psychics and astrologers, engaging in numerology and invoking portentous omens. For Crosthwaite, these attempts to ride supernatural currents and to weather cosmic eruptions are not simply the stuff of superstition; they are part of the vital substance of contemporary finance.

It is precisely such a threat of eruption that concerns Mike Hill and Warren Montag in their book, The Other Adam Smith (2015). Smith is most typically associated with the idea of the 'invisible hand' and its connotations of economic order and social harmony. In this Smith stands in for reason with a capital ' $R$ ', representing a modern drive to discover and harness the hidden laws that structure human societies. But Hill and Montag maintain that there is an 'other' Smith, whose fears of insurrection lead him to write at length about the fragility of society, stressing that within it which defies our desires and designs for organizational wholeness. On this reading, Smith is neither honored nor abused by those neoliberals that claim his legacy. There are many Adam Smiths, and in the movements and gaps between these we might begin to glimpse modernity's relation to unreason. In what follows I will use a series of figures - imagined, real, metaphorical - to highlight some tensions and absences within the works introduced above.

\section{Figures of finance}

The first of these figures is Eric Packer, a financial wunderkind whose data-driven fantasies lead him and the global economy to ruin in Don LeLillo's novel Cosmopolis (2003). Vogl begins and ends his book with the story of Packer, which he deploys, not unlike DeLillo himself, as an allegory of contemporary finance capitalism. For Vogl, Packer's story not only simulates how financial markets whip themselves up into speculative frenzies, but also reveals how these frenzies confront society as a kind of exterior, alien force. Vogl's Packer is thus the detached agent of an autonomous realm, his actions shaping the swirling information vortex that governs the lives of everyday people. Yuran (2014: 32) also invokes the figure of Packer, but he does so precisely in order to debunk the assumption that "finance occurs in a no-place, always remote from everyday experience". Put simply, we are all implicated in the workings of money and finance. Konings (2015: 2), too, takes aim at the image of finance as disembedded from society, seeing economy instead as a field charged with "morality, faith, power, and emotion". The question this raises is how the arcane workings of high-tech finance relate to the emotional logics of everyday life in capitalist societies. Can the magical worlds of money work without a wider audience that ultimately believes in magic? And if the specter of capital comes back to haunt us all, then why do we still seek solace in money's ghostly arms? Why does money possess this power?

The next figure I would like to highlight is that of the money worshipper - the person who, for whatever reason, acts as if he or she is too attached to money. Both Konings and Yuran discuss this figure at length but their conclusions point in different directions. According to Yuran, those who seem too attached to money simply register the truth of money's power to organize our desires. When people act as if all they want is more money, it is because this is 
what money itself wants. Money is thus the bearer of "an empty, negative desire" (Yuran, 2014: 71), and economic history the story of our becoming its agents. For Konings, money is indeed a powerful no-thing, but its power derives from its iconic status. Like the religious icons that came before it, money binds us to an invisible order by allowing us to understand without knowing. And just as in earlier debates over the religious idolater, the figure of the money worshipper works as a recurring trope, being used by people and groups to renew or reinvent the kinds of attachments to icons that they and others forge. Konings therefore attributes discursive power to the money-sign rather than positing money itself as a powerful object.

This divergence raises a number of questions. How does the money-form itself relate to the semiotic functioning of money-signs? Is it at all possible to account for the affective charge of money without considering both of these dimensions? And if the semiotic functioning of money displays a durable plasticity, with people inventing ever-new ways of relating to moneysigns, then should we not view money-forms in a similar light? Is there not something fundamentally pragmatic about the magical properties of money?

Continuing with the theme of our enigmatic attachment to money, my third figure is the technical analyst (or chartist) - a financial market professional who searches in streams of market data for signs of things to come, often drawing on supernatural discourses and their associated practices. For Crosthwaite (n.d.: 7), chartists unintentionally stage the truth of finance capitalism - namely, that it is a system founded on belief in the "existence and value of a host of mysterious and insubstantial entities". They also express, as Vogl (2015: 10) puts it, an alternative "will to knowledge" in the financial economy - an impulse to read the movement of asset prices not from an underlying sphere of earthly things but from a higher, cosmic plane of gods and deities.

This raises a question of how such impulses relate to those that underpin orthodox methods of financial analysis, as well as those that keep us returning to money itself as a means of structuring our individual and collective cosmologies. Does it matter that supernatural metaphors and practices exist in the financial world when the majority of financial institutions employ models based on assumptions of perfect rationality? How much weight should we give to outsider cosmologies when most people simply get on with the everyday rituals of using and making money? And lastly, what remains of the financial 'system' when we view it as made up of multiple milieus, each with its own ways of worldmaking?

This question of parts and wholes brings me to my fourth and final figure - the invisible hand. As Vogl points out, Adam Smith first uses this metaphor in his 1758 treatise, History of Astronomy, where it represents the limits to knowledge in polytheistic societies. When confronted with extraordinary phenomena, such as thunder or lightning, "the ancients would in the end simply turn to Jupiter's invisible hand" (Smith quoted in Vogl, 2015: 25). It is ironic, then, that Smith's economic rendering of Jupiter's hand would provide modern, 'rational' capitalism with one of its founding ideologies, and that the further this ideology was embedded into markets, the more unruly these markets would become, leading some to turn back to mythical portents in the sky. This is an irony, I am sure, that will not be lost on Hill and Montag. As they put it: "The work of sorting through Jupiter's fortune", using the tools of rational analysis, "comes up against limits in the form of everything else: those multitudes of causal factors, those multitudes that continue to 'rage', those historical forces variously said to be invisible, inarticulable rendered 'noise', or, simply, concealed" (Hill and Montag, 2015: 234). What they mean here is that there are always things beyond the ordered wholes we imagine, parts that cannot be grasped by rational thought, and which persist as a reminder that our systems of organization are partial, unstable, and subject to forces beyond them. 
This, for Hill and Montag, is something Smith both knows and fears. It is what leads him to invoke the hand of Jupiter at the very same time that he develops a rational argument for the division of labor in economic life. But what can we learn about today from the tensions in Smith's writings? What do these tensions reveal not just about Smith the thinker, but also the magical worlds of contemporary money and finance? In my view, Smith's crypto-spiritualism has been woven into our postmodern times - his ideas are themselves an input into the chaos of history, rather than a set of tools for sorting through it. If I am wrong, though, the question must then be: What is it in Smith that might provide purchase on the workings of twenty-first century capitalism?

\section{Money's magic}

I could go on, for there are many other points of intersection and divergence between these fascinating books. Instead I will end with one last question: Can financialized economies actually do without the magical worlds of money? If money itself is an unreasonable reality at once a thing without substance and a nothing without limit - then can we expect modern money economies to exhibit anything other than these same qualities? And in such a world, where money's magic is at once invisible and omnipresent, aren't our seemingly irrational money myths and practices the most rational of all possible responses?

\section{Acknowledgments}

On behalf of the editors I would like to thank Emily-Jane Cohen and Kalie Ann Caetano for helping to put the forum together and allowing us to republish material that first appeared on the Stanford University Press Blog.

\section{References}

Crosthwaite, P. (n.d.) Speculative Investments: Finance, Feeling, and Representation in Contemporary Literature and Culture. Unpublished manuscript.

DeLillo, D. (2003) Cosmopolis. New York, NY: Scribner.

Hill, M. and Montag, W. (2015) The Other Adam Smith. Stanford, CA: Stanford University Press. Konings, M. (2015) The Emotional Logic of Capitalism: What Progressives Have Missed. Stanford, CA:

Stanford University Press.

Vogl, J. (2015) The Specter of Capital, translated by J. Redner and R. Savage. Stanford, CA: Stanford University Press.

Yuran, N. (2014) What Money Wants: An Economy of Desire. Stanford, CA: Stanford University Press. 